\title{
Societal Progress of Corporate Social Responsibility-An Empirical Slant on Rastriya Ispat Nigam Limited (RINL, Visakhapatnam, India)
}

\author{
Venkata Naga Siva Kumar Challa*, Parimi SV Padmalatha, Burra Vamsi Krishna \\ Department of Management Studies, Ramachandra College of Engineering, Vatluru, Andhra Pradesh, India \\ Email: *challasivakumar2000@gmail.com,padmalatha35@gmail.com,vamsibu@gmail.com
}

How to cite this paper: Challa, V. N. S. K., SV Padmalatha, P., \& Krishna, B. V. (2021). Societal Progress of Corporate Social Responsibility-An Empirical Slant on Rastriya Ispat Nigam Limited (RINL, Visakhapatnam, India). Theoretical Economics Letters, 11, 686-694.

https://doi.org/10.4236/tel.2021.114046

Received: July 5, 2021

Accepted: August 1, 2021

Published: August 4, 2021

Copyright $\odot 2021$ by author(s) and Scientific Research Publishing Inc. This work is licensed under the Creative Commons Attribution International License (CC BY 4.0).

http://creativecommons.org/licenses/by/4.0/ Open Access

\begin{abstract}
Corporate Social Responsibility (CSR) recompenses several direct and indirect benefits to the business. The most important advantage of CSR is to provide a business organization with an improved social image. Shifting the accountability of serving to one another does not serve the purpose at all. Simply putting the mask of corporate social responsibility does not make an organization socially accountable rather the organization is literally warranted to interweave the philosophy of CSR into its mission to be socially answerable. Social responsibility includes the areas such as health, education, employment, poverty alleviation and quality of life. CSR must be made obligatory on the part of the corporate sector operating in the country. It is a matter of great contentment that the Government of India is in the process of taking certain statutory steps to pursue the corporate sector to have a proactive approach towards corporate social responsibility/community development. This paper contributes towards the societal development of CSR through four dimensions namely corporate social responsibility and its implementation, corporate social responsibility and sustainability, corporate social responsibility towards Goodwill, corporate social responsibility and Social Justice.
\end{abstract}

\section{Keywords}

Corporate Social Responsibility, Community Development, Sustainability, Goodwill, Quality of Work Life

\section{Introduction}

Corporate Social Responsibility (CSR) is a term that refers to the connection 
between a business and the broader community. Business must acknowledge its obligation to the community's wellbeing. Thus, the goal of every responsible corporation is to both give to and benefit from the community in which it works. CSR is defined as accepting responsibility for one's actions and promoting a beneficial effect on the environment, customers, workers, communities, and other stakeholders via one's operations. CSR transcends charity and demands businesses to go above and beyond their legal responsibilities, integrating social, environmental, and ethical issues into their business processes. Corporate social responsibility refers to the contributions that businesses make to society via their commercial operations and social investments (Ruzevicius \& Serafinas, 2007).

CSR is often referred to as "corporate citizenship" and may include incurring short-term expenditures that may not directly benefit the business but rather create good social and environmental change. The significance of corporate social responsibility (CSR) for society and the environment is waning in today's global age. It is definitely past time to consider those who are less wealthy and fortunate in society. Corporate social responsibility is critical for increasing brand awareness not just among rivals, but also among the media, other organizations, and, most importantly, among your direct consumers (Post, Lee, \& Preston, 2002). The purpose of CSR initiatives is not just to get attention, but also to instil a sense of commitment to the cause. As a result, the current research used a comprehensive approach to people's views of CSR in order to ascertain the variables that influence the implementation process. Additionally, the research discusses the distribution of CSR delivery mechanisms that contribute to societal fairness.

\section{Need for the Study}

The present study deals with the implementation of the CSR policy and their maintenance in the society in alignment with organizational strategy. In implementing the CSR initiatives, the identification needs of the society are most important. These identified needs processed through effective delivery mechanism by the beneficiaries who are engaged in CSR. Most of the studies of CSR deal only with assessment approach of CSR implementation; therefore, this lays a gap between the distributor of CSR and the receiver of CSR activities, in this case the beneficiary. Hence, the target group should integrate with organizational strategy to find out the hindrances in implementation of CSR. Different views exist in the minds of the target groups make for a case of disequilibrium of CSR policy.

To bridge the above-mentioned gap on delivering of CSR initiatives, the study is undertaken in a public sector company, Rastriya Ispat Nigam Limited, Visakhapatnam. The representatives of the company under study refer to the beneficiaries engaged in CSR activities. The effective implementation of CSR policy should integrate with organizational strategy in collaboration with legal perspective of CSR. On the other hand, people should receive the CSR initiatives irre- 
spective of the demographic factors. The dimensions of CSR initiatives should focus on not only the implementation of CSR but also in maintaining the CSR theme of the respective organization to improve the goodwill of the organization as well as the society in relation to which it helps in protecting social justice. Therefore, there is much requirement to study the dual strategic approach of CSR.

\section{The Study Objectives}

- To study the implementation process of corporate social responsibility.

- To understand how CSR affects its sustainability.

- To study the impact of CSR activities on enhancing the goodwill of the organization.

- To determine the role of CSR in promoting the social justice.

\section{Hypothesis of the Study}

- $\mathrm{H}_{1}$ : There is no impact of demographic factors on beneficiaries' perceptions towards CSR.

- $\mathrm{H}_{2}$ : There is significant impact of CSR implementation on the beneficiaries in enhancing the goodwill of the organization.

- $\mathrm{H}_{3}$ : The beneficiaries of CSR activities in the organization perceive that there is significant impact of CSR and its implementation towards promoting social justice.

- $\mathrm{H}_{4}$ : In the view of CSR beneficiaries, the CSR towards goodwill has impact in promoting social justice.

\section{Research Methodology \& Sample Determination}

The current research examines corporate social responsibility in relation to a strategic strategy taken by RINL. The implementation of CSR in the study with the integration of target group, namely the beneficiaries of CSR. The sample size of the study comprises of 155 CSR beneficiaries through RINL. In the target group the respondents in the sample are selected using simple random sampling technique. To know perceptions of CSR beneficiaries towards the implementation of CSR, detailed separate questionnaires are prepared. The various dimensions which are considered to deliver the opinion on implementation of CSR by the dual target groups, beneficiaries through RINL are enlisted under the following considerations.

The findings are concerned with the various perceptions of beneficiaries of corporate social responsibility through RINL which are segmented into four dimensions. Corporate social responsibility and its execution, corporate social responsibility and sustainability, corporate social responsibility and goodwill, and corporate social responsibility and social justice are among them. For the target groups the scores are allotted. Basing on these score values the individual average scores are calculated from each respondent for every dimension. The value is 
calculated by summation of each respondent divided by total number of variables of each dimension. The value so obtained is considered as individual scores. Basing on the individual scores, Chi-square test is conducted to test the significance level. For this a cross sectional between demographic factors and beneficiaries towards CSR is tabulated. To know the average scores provided by the beneficiaries of CSR towards different dimensions significantly same or not, "one-way Analysis of Variance" was carried out. In case of a situation where the average scores are significantly different, a further analysis using "t-test" for testing the significant difference between average scores provided by the beneficiaries of CSR is made for different combination of the pairs obtained from dimensions of the target group.

\section{Literature Review}

The contemporary idea that businesses have a social duty is not new. Indeed, the corporate concern for society may be traced back many centuries (Carroll, 2008).

Shuili Du, Bhattacharya, and Sankar Sen (2017) emphasize that by engaging in corporate social responsibility (CSR) activities, businesses can not only generate favorable stakeholder attitudes and more supportive behaviors (e.g., purchasing, seeking employment, investing in the company), but also build corporate image, strengthen stakeholder-company relationships, and enhance long-term value. Capaldi (2016) noted the contribution to resolving this conundrum. The purpose of this research was to ascertain the motivations, philosophies, and tactics behind CSR engagement by major multinational mining corporations operating in Ghana (Taghian et al., 2015). The impact of stakeholders on corporate social responsibility (CSR) efforts is examined by business management. Key stakeholders for a firm include the public, workers, unions, media, government, and shareholders. According to Nyuur et al. (2014), the conceptualization of CSR remains a gray area marked by disagreements about an accepted definition. It divides CSR into four duties in a pyramidal fashion to illustrate their relative significance and historical evolution, but maintains that all four coexist: Philanthropic Responsibilities, Ethical Responsibilities, Legal Responsibilities, and Economic Responsibilities. Deborah and Lois (2005) argue that since "Corporate Social Responsibility" (CSR) is essentially a function of markets and needs market-based incentives for businesses to engage in such programs, it is subject to the market's vagaries. George, Dahlander, Graffin, and Sim (2016) defined management research as a theme area concerned with reputation, prestige, and social assessment. We highlighted research that address critical issues related to the production or production of goodwill, reputation, image, or status, generally and informally referred to as "social evaluations", and how businesses seek, leverage, deploy, and profit from such social evaluations. Lourenco (2013) defined CSR in business rationale terms and stripped it of its normative component. Additionally, it has been suggested that providing the business case for problems such as 
CSR and sustainability in the framework of business education would likely make them more palatable to business students. Karen et al. (2006) note that companies are increasingly using Corporate Social Responsibility (CSR) efforts to influence customers and distinguish product offers. Their study contributes to an expanding corpus of marketing knowledge by manipulating customers' views of the fit, motive, and timing of corporate social activities incorporated in promotions.

\section{Research Gap}

The review of above research studies on corporate social responsibility practices in India and other countries gave the researcher a deep insight into the concept of corporate social responsibility and its other implications. It has come a long way, but still requires more comprehensive models with incorporation in strategic planning and social agendas of the companies. CSR and business ethics both deals with interests of the society but business ethics imply balance between meeting the internal set standards and to not harm the interests of the society globalization and pressure from key stakeholders have come up as the main driving forces behind the implementation of the cooperate social responsibility. The lack of awareness of stakeholders towards the legal compliance on CSR and implementation process leads to the research gap. The strategic planning of CSR policy and effective practice of the policy bridges the research gap between the target group. Hence it can be concluded that CSR practice is a core necessity of an organization which will help nourish the society as well as the organizational growth.

\section{Data Analyses}

\section{Test of equivalence among average scores of different dimensions towards beneficiaries of CSR:}

With a view to know whether the average scores provided by the beneficiaries of CSR towards the different dimensions namely CSR and its implementation, CSR and sustainability, CSR towards goodwill, CSR and social justice a one-way Analysis of Variance (ANOVA) was used. As the null hypothesis states that "there is no significant difference among the average scores provided towards the dimensions as opined by the beneficiaries of CSR" is rejected, a further analysis was made using $\mathrm{t}$-test for testing the significance of differences between different pairs of average scores of dimensions.

\section{ANOVA: Single Factor towards the Perceptions of CSR Beneficiaries in Rinl}

$\mathrm{H}_{0}$ : The average scores expressed by the beneficiaries on different dimensions namely, CSR and its implementation, CSR and sustainability, CSR towards promoting goodwill and CSR towards social justice are significantly same. Since 
p-value is $2.25 \mathrm{E}-17$ the $\mathrm{H}_{0}$ is rejected. Therefore, it can be concluded that the average scores expressed by the beneficiaries towards different dimensions of CSR are significantly different to each other.

That is the average opinion scores of beneficiaries towards different dimensions of CSR are varying. Therefore, it is further required to test the significant differences between their average scores of different pairs of dimensions. For this paired t-test is applied for all possible pairs and results are presented in Table 1.

From the Table 2 it can be inferred that, the average scores of beneficiaries towards implementation of CSR and CSR towards goodwill; implementation of CSR and promotion of social justice; CSR towards goodwill and promotion of social justice; are not significantly different. However, the average scores of beneficiaries towards implementation of CSR and CSR sustainability; CSR sustainability and CSR towards goodwill; CSR sustainability and promotion of social justice; significantly different. That is, except in cases of implementation of CSR and CSR towards goodwill, implementation of CSR and promotion of social justice, CSR towards goodwill and promotion of social justice in all other combinations of dimension of average scores of beneficiaries are significantly different. That is, the perceptions of beneficiaries towards four dimensions are same except in case of implementation of CSR and CSR sustainability; CSR sustainability and CSR towards goodwill; CSR sustainability and promotion of social justice.

Table 1. ANOVA: single factor towards the perceptions of CSR beneficiaries.

\begin{tabular}{ccccccc}
\hline Source of Variation & SS & df & MS & F & $P$-value & F critical value \\
\hline Between Groups & 12.91085 & 3 & 4.303618 & 28.68944 & $2.25 \mathrm{E}-17$ & 2.619367 \\
Within Groups & 92.40435 & 616 & 0.150007 & & & \\
Total & 105.3152 & 619 & & & \\
\hline
\end{tabular}

Table 2. Paired sample tests.

\begin{tabular}{|c|c|c|c|c|c|c|}
\hline Pair No. & Pair Combinations & $\begin{array}{c}\text { Mean of } \\
\text { difference of } \\
\text { Average scores }\end{array}$ & $\begin{array}{l}\text { Std. Deviation } \\
\text { difference of } \\
\text { average scores }\end{array}$ & Df & t-Value & $p$-Value \\
\hline Pair 1 & $\begin{array}{l}\text { Implementation of CSR- } \\
\text { CSR sustainability. }\end{array}$ & 0.32798 & 0.064212 & 154 & 6.359 & 0.000 \\
\hline Pair 2 & $\begin{array}{l}\text { Implementation of CSR- } \\
\text { CSR towards Goodwill }\end{array}$ & 0.02862 & 0.40841 & 154 & 0.872 & 0.384 \\
\hline Pair 3 & $\begin{array}{l}\text { Implementation of CSR- } \\
\text { Promotion of social justice }\end{array}$ & -0.03299 & 0.30468 & 154 & -1.348 & 0.180 \\
\hline Pair 4 & $\begin{array}{l}\text { CSR sustainability- } \\
\text { CSR towards Goodwill }\end{array}$ & -0.29935 & 0.81172 & 154 & -4.591 & 0.000 \\
\hline Pair 5 & $\begin{array}{l}\text { CSR sustainability- } \\
\text { Promotion of social justice }\end{array}$ & -0.36097 & 0.65267 & 154 & -6.886 & 0.000 \\
\hline Pair 6 & $\begin{array}{l}\text { CSR towards Goodwill- } \\
\text { Promotion of social justice }\end{array}$ & -0.06161 & 0.44458 & 154 & -1.725 & 0.086 \\
\hline
\end{tabular}




\section{Findings}

The Hypothesis $\left(\mathrm{H}_{1}\right)$ stating Employee involvement in CSR delivery mechanism has significant impact on employee orientation towards CSR statistically tested through $\mathrm{t}$-test has been accepted. Considerable efforts have been made by RINL at all phases of its CSR activities by involving its beneficiaries as catalysts for effective implementation which had created a clarity in the employees involved in comprehensive orientation towards CSR activities which is utmost required.

The Hypothesis $\left(\mathrm{H}_{2}\right)$ stating there is significant impact of CSR implementation on the beneficiaries in enhancing good will of the organization has been accepted. That is, the successful implementation of the CSR activities results in the enhanced satisfaction of the beneficiaries which in turn enhances the goodwill of the organization.

The Hypothesis $\left(\mathrm{H}_{3}\right)$ stating that the beneficiaries of CSR activities in the organization perceive that there is significant impact of CSR and its implementation towards promoting social justice is tested and accepted. That is, one of the most important mottos of CSR is promote social justice. The concept of social justice has to be imbibed at all phases of CSR activities. This has to been borne by beneficiaries involved in the implementation of CSR activities, so as to ensure that at every point should the concept of social justice.

The Hypothesis $\left(\mathrm{H}_{4}\right)$ stating that CSR beneficiaries viewed that CSR enhances goodwill of the organization which has a significant impact in promoting social justice has been statistically tested and has been accepted. That is the concerted efforts of the management of RINL, its beneficiaries involved in the delivery mechanism have resulted in fruitful results in enhancing the good will of the beneficiaries and thereby satisfying the concept of promoting social justice too.

\section{Recommendations}

Corporate social responsibility is not just a handy public relations tool; it is a necessary component of contemporary company success. The capacity of a corporation to exercise social responsibility may be the difference between a prospective beneficiary and a non-beneficiary, and today's customers are highly tuned in to determine whether or not a firm is a responsible global citizen. Additionally, good corporate social responsibility may help you improve your operations, increase employee morale, and even help you save money and remain competitive with your peers. Basing on the dual target groups the following suggestions should be implemented for effective application of CSR.

\section{- Quality of Skill and Peripheral Development}

Based on the present research findings, the quality of skill and peripheral development is totally revamped. The target group has to be correctly identified with age group of 16 - 35 years to give the best results to the stakeholders.

\section{- Contribute More Actively to the Community}

Enhancing corporate social responsibility requires developing a dual mentality and making global-impacting choices. Additionally, the business should be con- 
cerned with your immediate surroundings and actively strive to connect with your local community. The company should always look for opportunities to participate in community events, both to "do your part" and to ensure that the company's name is seen at significant local activities, allowing them to capitalize on the "soft marketing" and public relations benefits associated with being a responsible corporate citizen. To get the greatest outcomes, avoid treating local involvement as a sideshow or an afterthought. Rather than that, explicitly designate at least one member of the CSR team to organize several days of community service each quarter and ensure that the team knows its obligation to support those efforts and participate in any activities.

\section{- Contribute to the Local Community}

Apart from engaging in community events and other activities, it's critical to become a direct supporter of the local business community and businesses. Purchase from local suppliers, particularly if a significant portion of your company originates in the nearby region. Additionally, seek for methods to support local activities, particularly those that promote local companies.

\section{- Integrate CSR}

From top to bottom, the activities of CSR should be inter-connected and inter-twined as per company strategies. They radiate from the vision which initiates the CSR activity towards each and every beneficiary. These initiatives should be carefully examine with the organizational vision statement. The concerned CSR activity should capture an element of doing social good. These delivery mechanisms should be audited and assessed by communicating the sustainable business goals throughout the organization.

\section{- Communicate}

The CSR strategy should be built by mentioning the distribution of CSR activities or initiatives. These efforts should be conveyed to the public about acts of compassion; this will increase their likelihood of being interested in and participating in your experience. By using not just social media channels such as a blog, Twitter, or Facebook page, but also inbound channels such as staff meetings, board meetings, and press briefings. By increasing publicity of the initiatives, it brings full circle the attention to what one's brand is doing.

\section{Conclusion}

The study has given a significant understanding towards the acceptance of skill and peripheral development by the stakeholders i.e., beneficiaries. Since the problem of skill and peripheral development programmes delivered to the stakeholders with respect to the quality is not within the scope of study, it is required to be taken up as future agenda. The Government of India, through its "skill India program" has made public sectors in India commit a part of the profits as CSR contribution specifically for skill development. In future studies, I recommend a comparative analysis between public and private sectors on the perceptions of employees and beneficiaries towards CSR. The scope of further 
research can specify the sensitive areas of CSR like CSR-centred core values that help to set milestones and enable businesses to plan and share goals.

\section{Conflicts of Interest}

The authors declare no conflicts of interest regarding the publication of this paper.

\section{References}

Capaldi, N. (2016). New (Other?) Directions in Corporate Social Responsibility. International Journal of Corporate Social Responsibility, 1, Article No. 4. https://doi.org/10.1186/s40991-016-0005-5

Carroll, A. B. (2008). A History of Corporate Social Responsibility: Concepts and Practices. In A. M. A. Crane, D. Matten, J. Moon, \& D. Siegel (Eds.), The Oxford Handbook of Corporate Social Responsibility (pp. 19-46). New York: Oxford University Press. https://doi.org/10.1093/oxfordhb/9780199211593.003.0002

Deborah, J. W., \& Lois, A. M. (2005). The Effects of Corporate Social Responsibility and Price on Consumer Responses. Journal of Consumer Affairs, 39, 121-147. https://doi.org/10.1111/j.1745-6606.2005.00006.x

Du, S., Bhattacharya, C. B., \& Sen, S. (2017). Maximizing Business Returns to Corporate Social Responsibility (CSR): The Role of CSR Communication. International Journal of Management Reviews, 12, 8-19. https://doi.org/10.1111/j.1468-2370.2009.00276.x

George, G., Dahlander, L., Graffin, S., \& Sim, S. (2016). Reputation and Status: Expanding the Role of Social Evaluation in Management Research. Academy of Management Journal, 59, 1-13. https://doi.org/10.5465/amj.2016.4001

Karen, L., Becker-Olsena, B., Andrew, C., \& Ronald, P. H. (2006). The Impact of Perceived Corporate Social Responsibility on Consumer Behavior. Journal of Business Research, 59, 46-53. https://doi.org/10.1016/j.jbusres.2005.01.001

Lourenco (2013). Corporate Social Responsibility in International Marketing: Review, Assessment, and Future Research. International Marketing Review, 33, 580-624.

Nyuur, R. B., Ofori, D. F., \& Debrah, Y. (2014). Corporate Social Responsibility in Sub-Saharan Africa: Hindering and Supporting Factors. African Journal of Economic and Management Studies, 5, 93-113. https://doi.org/10.1108/AJEMS-01-2012-0002

Post, E., \& Lee, E. (2002). Redefining the Corporation: Stakeholder Management and Organizational Wealth. Redwood City: Stanford University Press.

Ruzevicius, J., \& Serafinas, D. (2007). The Development of Socially Responsible Business in Lithuania. Engineering Economics, 1, 36-43.

Taghian, M., D’Souza, C., \& Polonsky, M. (2015). A Stakeholder Approach to Corporate Social Responsibility, Reputation and Business Performance. Social Responsibility Journal, 11, 340-363. https://doi.org/10.1108/SRJ-06-2012-0068 